\title{
CHANGES IN COGNITIVE FUNCTIONING AS AN EFFECT OF COMPLEX TREATMENT OF MYOFASCIAL PAIN IN TEMPOROMANDIBULAR DISORDERS
}

\author{
Joanna Biegańska-Banaś ${ }^{1,2}$, Małgorzata Pihut ${ }^{3}$, Józef Gierowski ${ }^{4}$, Ewa Ferendiuk ${ }^{3}$ \\ 'Department of Medical Psychology, Chair of Psychiatry, Jagiellonian University Medical College, Cracow, Poland \\ ${ }^{2}$ Chair of Psychology, SWPS University of Social Sciences and Humanities, Warsaw, Poland \\ ${ }^{3}$ Department of Dental Prosthetics, Jagiellonian University Medical College, Cracow, Poland \\ ${ }^{4}$ SWPS University of Social Sciences and Humanities, Katowice, Poland
}

\begin{abstract}
InTRODUCTION: Pain reduction is a benefit that comprehensive treatment of myalgic temporomandibular disorders can provide. Myalgic pain reduction is associated with a series of changes at the neurophysiological level, which are inseparably connected with psychoemotional and cognitive changes. It has not been established if the course of these changes is the same for chronic myofascial pain in temporomanibular disorders as it is for other types of chronic pain.

ОвјестіVEs: The present study examined changes in cognitive functioning among patients with myofascial pain before and after three months of prosthetic treatment supplemented with psychoeducational and physiotherapeutic therapy.

MATERIAL AND METHODs: Participants were 45 patients, 23 were people with painful myofascial temporomandibular disorders and 22 were people with disorders of the same type who did not complain about pain symptoms. Statistical analysis included group comparisons of verbal learning, perceptiveness, attention, verbal fluency, immediate and working memory as well as selected executive functions measured with a number of psychological tests and neuropsychological clinical trials.

RESULTS: Analyses based on two-sided dependent samples t-tests as well as the Fisher's LSD tests conducted in the analysis of variances showed therapeutic effects, both, with reference to chosen spheres of cognitive functioning, which initially differentiated the control and research groups, as well as the ones which did not differentiate these two groups.

ConcLusions: The results of this study indicate that cognitive functioning undergoes dynamic changes in the initial phase of treatment. Some of these changes may be specific for myofascial pain. The awareness about those changes may appear to be essential for planning therapeutic procedures and beneficial to maintain patient's engagement in the process of treatment.
\end{abstract}

KEY WORDS: myofascial pain, temporomandibular disorders, cognitive functions, psychostomatology.

J Stoma 2018; 71, 4: 322-332

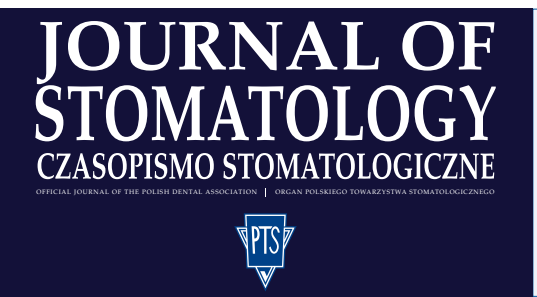

ADDRESS FOR CORRESPONDENCE: Joanna Biegańska-Banaś, Department of Medical Psychology, Chair of Psychiatry, Jagiellonian University Medical College, 21A Kopernika St., 31-126 Cracow, phone: 5051154 432,e-mail: jbieganska@st.swps.edu.pl 
DOI: https://doi.org/10.5114/jos.2018.83405

\section{INTRODUCTION}

\section{NEUROPHYSIOLOGY OF CHEWING ORGAN}

The system of chewing organ is an incredibly complex morphological and functional unit that consists of teeth, teeth suspension system, mandibular joints, ligaments, and muscles. Among the latter ones, the following group of muscles can be differentiated: masseters, suprahyoid muscles, infrahyoid muscles, facial muscles, tongue muscles, and soft palate muscles. Each of them is innervated by cranial nerves (trigeminal nerve $-\mathrm{V}$, facial nerve - VII, tongue and throat nerve - IX, vagus nerve $-\mathrm{X}$ ) and spinal nerves (C1-C4) with parasympathetic fibers within cranial nerves. These nerves include afferent nerve fibers (attracting impulses from receptors to central nervous system) as well as efferent nerve fibers (conducting impulses to muscles). Properly shaped system of chewing organ allows mutual and synchronic cooperation of all those elements, coordinated by efficiently functioning nervous system.

As showed in a research [1], only such cooperation has beneficial impact on the work of neuro-anatomical structures, increasing the blood flow to somatosensory cortex, motor cortex, insula, striatum, thalamus, and cerebellum. Briefly, these fields are jointly responsible for analysis, control, and integration of sensory and motor functions. The thalamus itself plays an essential role in attention processes and controlling access of sensory data, and is included in limbic system responsible for controlling memory processes, steering motivation, and regulation of emotional activity. The cerebellum, however, is important for efficient executive functioning [2-4], language [5], sight-spatial [6], memory (concerning procedural memory that is automation of cognitive functions [7], operative memory [8,9], and long-term memory [10]) as well as emotions and personality [11-15].

Research results are, therefore, not surprisingly indicating that properly shaped chewing mechanism, starting chewing system before cognitive task, increases the level of oxidized blood (BOLD) in neuro-anatomical structures relevant in cognitive functions important for every day functioning [16-20]. Functional observations, which are taking place during performance of cognitive tasks as well as during control of stomatognathic system, enable to separate specific relations between chewing system and cognitive functions [21-23]. On the basis of that general conclusion, as a principle, chewing helps to enhance different perception and mo- tor functions, attention, executive or memory function, although not all of them (e.g., it weakens average reaction time), regardless of teeth condition (e.g., dental curve shortened by molar teeth bears the relations observed).

\section{PSYCHO-NEUROPHYSIOLOGICAL MECHANISMS IN CHEWING ORGANS DISORDERS}

Emotions constitute an essential etiological factor of functional disorders of chewing organ, with muscle component dominance understood as psychosomatic disorders: „ $(\ldots)$ in the course of which psychic factors play an essential role in appearance of symptoms of illnesses, their increase and end" [24]. Empirical research devoted to those disorders investigates them, first and foremost, as a consequence of psychological stress experienced [25-35]. Mediating role is played in this case by reticular formation, which activated by structures of brain stem, stimulates so called " $\gamma$ wave". Cell bodies of $\gamma$ are to be found in front corners of spinal cord through fibers reaching sensory receptors of muscles-neuromuscular spindles, regulating volatility of the latter ones [36, 37]. That is why evoking strong emotions results in launching activity of muscles that draw the jaws.

Disorders of natural functions of chewing organ muscles originate from a number of events of both site (e.g., breaking of a tooth, damage of tissue) as well as general ones (virus infection, emotional stress) [38-40]. Among them, the most commonly discussed in literature are: occlusion, injury, deep pain stimulus, stress, and parafunctions [41]. In majority of cases when these events do not appear widely, phenomenon quickly withdraws, and muscles return to their original functions. Otherwise, muscles react with so called "co-contraction" (contraction) and if prolonging with time, enhances local (biochemical) and global (structural) changes.

Excessive activity of lateral pterygoid muscle having its insertion, among others, within front part of joint disc, results in its pathological dislocation, enhances weakening of joint head and disc coordination during jaw movements, and increases appearance of acoustic symptoms in form of clicks [32]. Further results of muscle tension include damage of hard tissues of teeth in the form of cracks of clinic dental crown enamel and creation of defects or pathological abrasion of teeth. Apart from the above, there are pathological changes in peridontal tissues and uncontrolled bone losses as well as destruction of temporomandibular joint structures, strain, and development of chewing muscles. This in turn does not remain without any influence on certain cognitive functions coordinated by certain brain structures [42]. Mediating function in this case is fulfilled by brain-derived neurotrophic factor 
(BDNF) as well as its receptor, TrkB, dysfunctions within chewing organ enhancing lowering of progenitor cells level (kind of stem cell used for regeneration process) and functional neurons as a result of action of BDNF tracts removal from adjustment [43]. All the above-named changes are often accompanied by chronic pain, which itself is full of negative emotions, enhancing weakening of cognitive functioning strengthens psycho-neurophysiological mechanisms $[44,45]$.

\section{INFLUENCE OF CHRONIC PAIN ON CHANGES IN COGNITIVE FUNCTIONING}

The effect of preserved muscle injury and further changes in muscle tissues is developed due to constant pain. When it lasts longer than 3 months or remains unchanged despite removing the reason of its occurrence, diagnosis of chronic pain can be evaluated. As such, the experience of pain has an impact on central nervous system enhancing further muscle and brain reactions. Although nervous system can adapt its functions and start compensation processes, it is not, however, able to repair the dysfunction created. Chronic pain lowers cognitive functioning of patients mainly in the scope of attention, psychomotor fitness, memory but also executive functions $[46,47]$. Diagnostic image research carried out both on people and animal (rats) proved neuroanatomical changes as a result of untreated, chronic pain comprising the volume of grey matter, integrity of white cortex, and epigenetic changes in central nervous system [48-51], observed also in case of myofascial pain in temporomandibular disorders $[52,53]$. What is interesting, they also appear in case of phantom pain after amputation or spinal cord injury, confirming chronic experience of pain, even partially $[54,55]$.

These changes are not placed by accident, which can be seen from empirical reports devoted to pain of different systems; however, they appear in defined, functionally specific neuroanatomical regions, engaged in nociceptive processing of pain through supraspinal canal. They concentrate mainly around cingulate cortex, prefrontal cortex, insular cortex, and dorsal part of pons. Further structures include thalamus, prefrontal cortex, basal ganglia, and hippocampus. Observed neuroanatomical changes in those fields are reflected in cognitive functioning of patients [56-59].

Research shows that observed structural changes within central nervous system can be, at least partially, reversible [60-65], whereas these processes may last even for few years. Some reports suggest that under the influence of standardization of neuroanatomical processes being the effect of pain termination, psychophysical functioning of patients improves [66].

\section{OBJECTIVE}

The aim of our study was to observe possible changes in cognitive functioning of patients with pain in the course of functional disorders of chewing organ with majority of muscle component, treated with the use of occlusal guards, and simultaneously provided with physiotherapeutic and psycho-educational impact.

\section{MATERIAL AND METHODS}

The study described in the article was a part of bigger research project. The analysis included the results of twenty-three patients from the treatment group, aged 20 to 75 years $(M=35.39$; $S D=11.03), 14$ women and 9 men, and twenty-two subjects from the control group aged 24-53 years $(\mathrm{M}=35.06$; $\mathrm{SD}=9.49)$, consisted of 13 women and 9 men. The subjects were recruited from a group of patients diagnosed with a painful form of muscle-related functional masticatory organ disorders, who arrived at the clinic for the first time with the purpose of diagnosis and treatment. The exclusion criteria included patients' will and the general diseases that prevented planned test procedures. Financial compensation for participation in the study was not provided; however, the patients had an opportunity to attend five psychoeducational meetings with a psychologist aimed at increasing awareness of a psychogenic factor in functional masticatory organ disorders and better coping with stress by learning techniques to reduce the level of perceived psychophysical tension. The research was longitudinal type and was conducted with the use of psychological questionnaires measuring current and/or previous experience of pain as well as quality of life among patients with temporomandibular joint disorders, in addition to psychological tests of paper-and-pencil type and computer clinical trials involving tasks that measure specific cognitive functions.

Test battery consisted of:

- Demographic survey - designed by the author to gather basic socio-demographic data, as well as information about some of the variables controlled in the study, including duration of pain experience, previous treatment, pharmacological background (drugs used, doses etc.).

- Visual Analogue Scale (VAS) - a $100 \mathrm{~mm}$ straight line with a clearly marked beginning (no pain) and end (unbearable pain). Each participant was asked to mark a point on the scale corresponding to the experienced severity of pain.

- Pain Evaluation Sheet (Szatanik): this is a shortened version of the McGill-Melzack pain questionnaire. Original tool consists of 78 adjectives (descriptors) divided into 3 classes: sensory, affective, and evaluative. Each examined person chooses descriptors that best describe currently experienced pain. Version of the tool, which is going to be used in this project is simplified and consists of 43 words divided into 2 categories: sensory and emotional. Reliability (Cron- 
bach's $\alpha$ ) of this questionnaire is acceptable (0.6-0.81);

- Californian Verbal Learning Test (RVLT): this test requires subject to try to repeat a list of 16 words previously read. This procedure is repeated five times, then the researcher reads a different list of 15 words, and each person is asked to repeat it. At that time, the examinee is asked to try to repeat words from the first list;

- Attention and Perception Test (Test Uwagi i Spostrzegawczości - TUS): each subject is asked to mark (during three minutes) some symbols among different but similar ones (e.g., numbers 3 and 8) among others. Each person will be administered one of two equal versions of the task;

- Digit Span Test (DST) - a subscale of the Wechsler Intelligence Scale (WAIS-R(PL)), in which the subject is required to repeat 3-9 digits forward and then 2-9 digits backward. This subscale measures working memory, attention and concentration.

- Color Trail Test (CTT): this test consists of two parts, $\mathrm{A}$ and $\mathrm{B}$. It requires an immediate recognition of symbolic meaning of numbers and letters as well as an ability to repeatedly eye-search the entire worksheet in order to find the following number or letter under time pressure;

- Verbal Fluency Test: each person is supposed to generate words beginning with an indicated letter for a period of 1.5 minutes, and then to generate words belonging to a category indicated by the researcher for the next 1.5 minutes;

- Wisconsin Card Sorting Test (WCST) (computer version) - the subject is presented with 4 sample cards and must then organise up to 128 cards according to a given rule (colour, number or shape). This tool is frequently used to measure aspects of cognitive control.

- Go-No Go clinical trial (computer version) - the subject is asked to react by pushing a button when a specified letter (e.g. $p$ ) is presented on the screen and not to react if another letter (e.g. $r$ ) is presented. In the second part of the trial, the person is asked to react when they see $r$ and not when they see $p$. This is a commonly used measure of cognitive control.

Battery of tests was taken twice by each participant (for both experimental and control group), before and after the treatment (in 3-month time). The order in which the tools are listed corresponds to the order in which they were used. The results of the pain evaluation sheet were not included in this article.

\section{STATISTICAL ANALYSIS}

The investigation included intragroup and intergroup comparisons. Intragroup comparisons concerning the treatment group were carried out using the dependent (paired) samples $t$-test. Following this plan, the differences in the intensity of pain, auditory verbal learning, attention and perceptiveness, short and working memo-

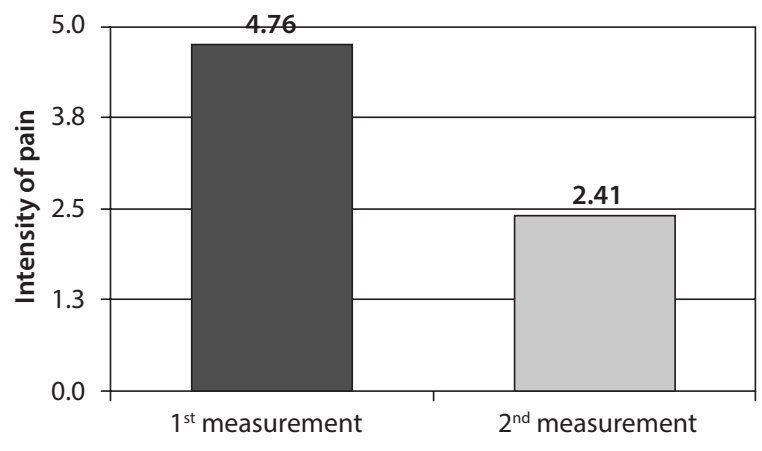

FIGURE 1. The mean values of the intensity of pain in the treatment group

ry, continuity of attention and alternating attention, and verbal fluency were analyzed. Analyses concerning comparison of the treatment group and the control group in terms of differences between the first and the second measurements were performed using a repeated measures analysis of variance in the mixed-effects model, taking into account being in the treatment group or control group as the between-subject factor. This type of analysis was carried out for the results of Go/No go trials and the Wisconsin Card Sorting Test.

\section{RESULTS}

\section{INTRAGROUP COMPARISONS}

\section{THE INTENSITY OF PAIN}

The mean value of the results on the VAS scale obtained in the treatment group in the first measurement was $4.76(\mathrm{SD}=2.66)$ and was higher than the mean value obtained in the second measurement, which was $2.41(\mathrm{SD}=0.43)$ (Figure 1). Based on the value of dependent samples $t$-test, it was found that the obtained difference was statistically significant, $t(22)=7.64, p<0.001$.

\section{AUDITORY VERBAL LEARNING}

Statistically significant differences were observed between the mean values of the auditory verbal learning test results obtained in the treatment group in the first and the second measurements (Table 1). Two-sided dependent samples $t$-test was included. The mean values of the results of the auditory verbal learning test obtained in the treatment group in the first measurement and the second measurement with the test of statistical significance was added to the summary.

Results of analyses allow to claim that the mean values of the outcome occurred in the first trial, and the fourth trial were higher in the second measurement than in the first measurement. 
TABLE 1. The mean values of the results of the Auditory Verbal Learning Test obtained in the treatment group in the $1^{\text {st }}$ measurement and $2^{\text {nd }}$ measurement with the test of statistical significance

\begin{tabular}{|c|c|c|c|c|c|c|c|}
\hline \multicolumn{8}{|c|}{ Measurement } \\
\hline \multirow[t]{2}{*}{ Variable } & \multicolumn{2}{|c|}{$1^{\text {st }}$ measurement } & \multicolumn{2}{|c|}{$2^{\text {nd }}$ measurement } & \multirow[t]{2}{*}{$t$} & \multirow[t]{2}{*}{ df } & \multirow[t]{2}{*}{$p$} \\
\hline & M & SD & M & SD & & & \\
\hline $1^{\text {st }}$ trial & 6.37 & 1.86 & 7.42 & 1.74 & $-4.73^{* * * *}$ & 18 & 0.001 \\
\hline $2^{\text {nd }}$ trial & 9.32 & 2.36 & 10.00 & 2.19 & -1.38 & 18 & 0.185 \\
\hline $3^{\text {rd }}$ trial & 11.85 & 2.25 & 12.35 & 1.66 & -1.17 & 19 & 0.255 \\
\hline $4^{\text {th }}$ trial & 12.70 & 2.00 & 13.55 & 1.67 & $-2.17^{*}$ & 19 & 0.043 \\
\hline $5^{\text {th }}$ trial & 13.60 & 1.79 & 14.35 & 1.60 & -1.75 & 19 & 0.096 \\
\hline
\end{tabular}

$M$ - mean value; $S D$ - standard deviation; $t$ - test statistic; $d f$ - degrees of freedom;

$p$ - two-sided statistical significance; ${ }^{*} p<0.05 ;{ }^{* * *} p<0.01$

\section{ATTENTION AND PERCEPTIVENESS}

Further analyses based on two-sided dependent samples $t$-test showed statistically significant differences between the mean values of the results of the attention and perceptiveness test obtained in the treatment group in the first and the second measurements. What is worth noting, the significant effect concerned number of proper answers only $(t=-2.57, \mathrm{df}=20 ; p=0.018)$ and did not concern the total number of responses $(t=-1.62$, $\mathrm{df}=20 ; p=0.122)$. The mean value obtained in the second measurement was higher than the mean value obtained in the first measurement (Figure 2).

\section{VERBAL FLUENCY, CONTINUITY OF ATTENTION, AND ALTERNATING ATTENTION}

Analyses using two-sided dependent samples $t$-test did not indicate statistically significant differences between mean values of the results obtained in the treatment group in the first measurement and the second measurement for verbal fluency. The effect included both semantic and lexical verbal fluency at all stages of the measurement (after $30 \mathrm{sec}$., after $60 \mathrm{sec}$. and after

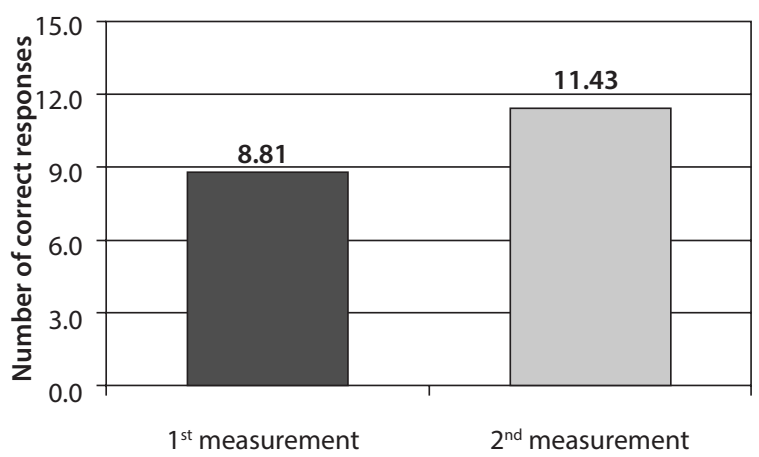

FIGURE 2. The mean values of the results of the attention and perceptiveness test obtained in the treatment group in the $1^{\text {st }}$ measurement and $2^{\text {nd }}$ measurement
90 sec.).

Similarly, two-sided dependent samples $t$-test analyses did not reveal statistically significant differences between the mean values of results obtained by the subjects in none of two measurements conducted with the trail making test.

\section{IMMEDIATE AND WORKING MEMORY}

The mean values of the results of the digit span task obtained in the treatment group in the first measurement and the second measurement turned out to be statistically significant $(t=-6.87, \mathrm{df}=14 ; p=0.001$ for words given forwards, and $t=-2,74, \mathrm{df}=15 ; p=0.015$ for words given backwards). In both cases, the mean values of the results obtained in the second measurement were higher than the mean values obtained in the first measurement (Figure 3).

\section{INTERGROUP COMPARISONS AND DIFFERENCES BETWEEN THE FIRST AND THE SECOND MEASUREMENT}

\section{REACTION TIME}

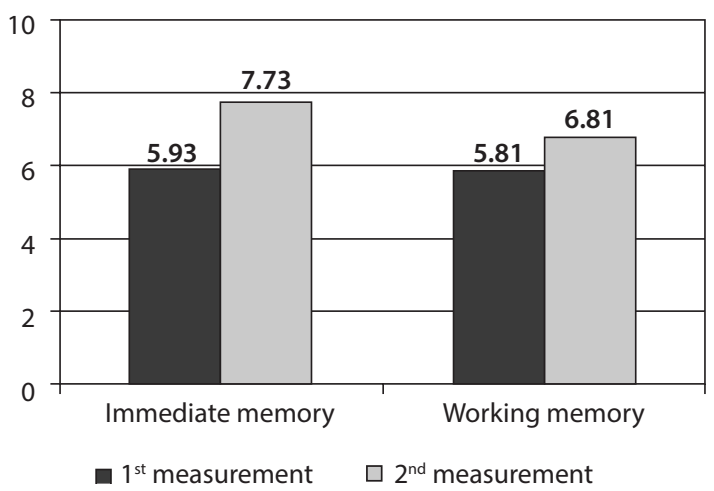

FIGURE 3. The mean values of the results of the digit span task obtained in the treatment group in the $1^{\text {st }}$ measurement and $2^{\text {nd }}$ measurement 
TABLE 2. The mean values of the results of the Wisconsin Card Sorting Test obtained in the $1^{\text {st }}$ measurement and $2^{\text {nd }}$ measurement in the whole surveyed sample with the test of statistical significance

\begin{tabular}{|c|c|c|c|}
\hline \multicolumn{1}{|c|}{ Variable } & F & df & p \\
\hline Categories achieved & $5.48^{*}$ & 1.40 & 0.024 \\
\hline Number of trials & 0.78 & 1.40 & 0.384 \\
\hline Total number correct & $4.42^{*}$ & 1.40 & 0.042 \\
\hline Total errors & 1.62 & 1.40 & 0.210 \\
\hline Perseverative responses & 2.35 & 1.40 & 0.133 \\
\hline Perseverative errors & 1.32 & 1.40 & 0.257 \\
\hline Non-perseverative errors & 3.04 & 1.40 & 0.089 \\
\hline Trials to complete first category & $21.63^{* * *}$ & 1.40 & 0.001 \\
\hline Failure to maintain set & 0.43 & 1.40 & 0.517 \\
\hline Learning to learn & 0.22 & 1.40 & 0.647 \\
\hline Conceptual level responses & 0.50 & 1.40 & 0.482 \\
\hline
\end{tabular}

$M$ - mean value, $S D$ - standard deviation, $F$ - test statistic, $d f$ - degrees of freedom, $p$-two-sided statistical significance

The within-subjects effects test conducted in the analysis of variance indicated statistically significant differences for the number of errors between the mean values of the results of go/ no-go trials obtained in the first and the second measurement in the whole surveyed sample: $\mathrm{F}=17.71, \mathrm{df}=1.41 ; p=0.001$. The mean value obtained in the second measurement was higher than the mean value obtained in the first measurement. However, no interactive effects between the treatment group and the control group, and the differences between the first and the second measurements both for correct answers
$(\mathrm{F}=1.36, \mathrm{df}=1.41 ; p=0.250)$ and number of errors $(\mathrm{F}=0.10, \mathrm{df}=1.41 ; p=0.755)$ were found.

\section{EXECUTIVE FUNCTIONS}

Table 2 shows the mean values of the results of the Wisconsin card sorting test obtained in the first and the second measurements in the whole surveyed sample (research group and control group analyzed overall). The test of statistical significance of within-subjects effects conducted in the analysis of variance was added to the summary.

Statistically significant difference between the first measurement and the second measurement was observed for the number of correct responses, errors, perseverative errors, trials to complete the first category, and conceptual level responses. The mean values obtained for the number of correct responses and conceptual level responses were higher in the first measurement than in the second measurement, while the mean values obtained for the number of errors, perseverative errors, and trials to complete the first category were higher in the second measurement than in the first measurement.

The test of interactive effects between the treatment or control group and difference between the first and the second measurement for values of the results of the Wisconsin card sorting test (Table 3) indicated statistically significant interactive effects for categories achieved, total number correct, and trials to complete the first category.

Figure 4 shows the mean values of the number of categories achieved in the first and the second measurement in the treatment and control groups. Paired

TABLE 3. The mean values of the results of the Wisconsin Card Sorting Test obtained in the $1^{\text {st }}$ measurement and $2^{\text {nd }}$ measurement in the whole surveyed sample with the test of statistical significance

\begin{tabular}{|c|c|c|c|c|c|c|c|}
\hline \multicolumn{8}{|c|}{ Measurement } \\
\hline \multirow[t]{2}{*}{ Variable } & \multicolumn{2}{|c|}{$1^{\text {st }}$ measurement } & \multicolumn{2}{|c|}{$2^{\text {nd }}$ measurement } & \multirow[t]{2}{*}{$\mathbf{F}$} & \multirow[t]{2}{*}{ df } & \multirow[t]{2}{*}{$p$} \\
\hline & M & SD & M & SD & & & \\
\hline Categories achieved & 2.95 & 1.46 & 2.86 & 1.42 & 0.46 & 1.40 & 0.501 \\
\hline Number of trials & 62.74 & 3.05 & 62.98 & 3.54 & 0.78 & 1.40 & 0.384 \\
\hline Total number correct & 45.40 & 10.89 & 41.17 & 10.04 & $16,57^{* * *}$ & 1.40 & 0.001 \\
\hline Total errors & 17.31 & 10.60 & 21.60 & 10.22 & $17.83^{* * *}$ & 1.40 & 0.001 \\
\hline Perseverative responses & 21.50 & 6.89 & 21.98 & 8.29 & 0.37 & 1.40 & 0.545 \\
\hline Perseverative errors & 10.93 & 7.12 & 12.52 & 9.25 & $4.74^{*}$ & 1.40 & 0.035 \\
\hline Non-perseverative errors & 7.74 & 6.88 & 8.88 & 6.22 & 2.78 & 1.40 & 0.103 \\
\hline Trials to complete first category & 13.02 & 5.70 & 17.57 & 10.07 & $18.92^{* * *}$ & 1.40 & 0.001 \\
\hline Failure to maintain set & 0.33 & 0.72 & 0.38 & 0.76 & 0.43 & 1.40 & 0.517 \\
\hline Learning to learn & 5.55 & 4.90 & $-9,457.54$ & $41,214.95$ & 0.22 & 1.14 & 0.647 \\
\hline Conceptual responses & 37.29 & 12.97 & 34.48 & 13.35 & $7.39^{*}$ & 1.40 & 0.010 \\
\hline
\end{tabular}

$M$ - mean value, $S D$ - standard deviation, $F$ - test statistic, $d f$ - degrees of freedom, $p$ - two-sided statistical significance ${ }^{*} p<0.05,{ }^{* * *} p<0.001$ 
comparisons carried out for the values obtained in the first measurement and the second measurement separately in the treatment group and control group show that the mean value of categories achieved in the treatment group was higher in the second measurement than in the first measurement, $t(21)=-2.01$, $p<0.05$, while there was no statistically significant difference between the mean values obtained in the first and the second measurement in the control group: $t(19)=1.28, p>0.05$.

Figure 5 shows the mean values of the number of correct responses in total in the first and the second measurements in the treatment group and control group. Paired comparisons carried out for the values obtained in the first measurement and the second measurement separately in the treatment group, and the control group allow to conclude that the mean value of categories achieved in the treatment group was higher in the second measurement than in the first measurement: $t(21)=-4.59, p<0.001$, while there was no statistically significant difference between the mean values obtained in the first and the second measurements in the control group: $t(19)=-1.32, p>0.05$.

Figure 6 shows the mean values of the number of trials to complete the first category in the first and the second measurements in the treatment group and control group. Paired comparisons carried out for the values obtained in the first measurement and the second measurement separately in the treatment group and the control group allow to conclude that the mean value of categories achieved in the treatment group was lower in the second measurement than in the first measurement: $t(21)=5.55, p<0.001$, while there was no statistically significant difference between the mean values obtained in the first and the second measurements in the control group: $t(19)=-0.27, p>0.05$.

\section{DISCUSSION}

After a few weeks of complex therapy including the use of occlusal guards with accompanying impact of manual physiotherapy and psycho-education clear, the reduction of pain has been achieved. This confirms empirical reports' results published earlier, indicating effectiveness and justifiability of such a form of therapy during the first phase of treatment [67, 68]. Presence of guards leads to an increase in vertical dimension, relieving temporomandibular joints, and a decrease in excessive activity of chewing muscles and front temporal muscles, the effect of equal division of occlusive power [69]. Physiotherapy focuses on improvement of jaw movement, improvement of chewing muscles movement, and eliminating joints' pain [70]. Psychological impact should strongly concentrate on this phase, among others, on improvement of coping with psychological stress accompanying chewing organ disorders, change of think-

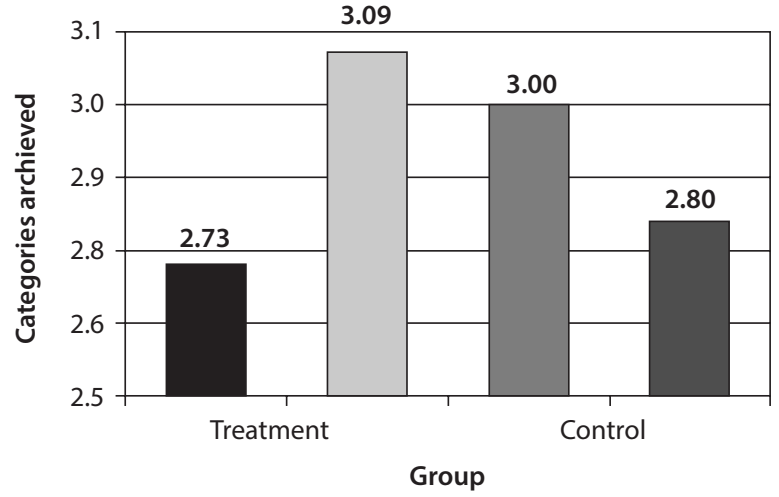

FIGURE 4. The mean values of the number of categories achieved in the Wisconsin Card Sorting Test in the $1^{\text {st }}$ measurement and $2^{\text {nd }}$ measurement in the treatment group and the control group

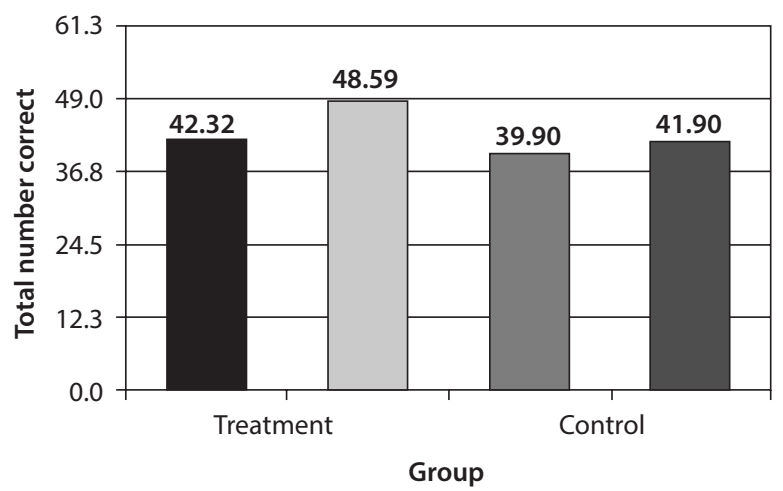

FIGURE 5. The mean values of total number correct in total in the $1^{\text {st }}$ measurement and $2^{\text {nd }}$ measurement in the treatment group and control group

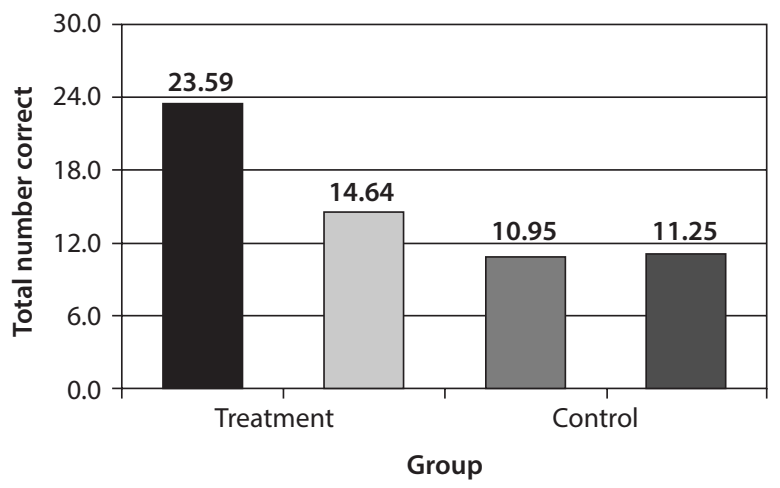

FIGURE 6. The mean values of the number of trials to complete the first category in the Wisconsin Card Sorting Test in the $1^{\text {st }}$ measurement and $2^{\text {nd }}$ measurement in the treatment group and control group

ing habits and behavior used to reduce pain [71-75]. Psychologically, rewarding meaning of reduction of pain is important being the effect of initial phase of treatment but also neurophysiological, connected with protection of central nervous system [76-78]. 
Results of a research suggests that changes in word fluency in a research group seem to be rather permanent; despite of clear weakening of pain, no substantial improvement in carrying out tasks was noted focusing on assessment of this cognitive function [7]. Slight increase in the number of words observed was not achieved; however, essential statistical level in re-test is probably connected with the effect of learning $[79,80]$. It can be assumed that more definite tendency in the scope of results improvement could be observed in a longer period of time. Consistent lack of improvement in the scope of word fluency in the observed group of patients can result from the fact of complex possibilities, which is reflected in observed results in possibility of word fluency such as executive functions and operative memory, lexical sources of long-term memory as well as connected with lack of functional and structural disorders within temporal and frontal lobe's structure of brain [79, 81-86]. Simultaneously, possible improvement of performance requires parallel improvement in other fields of cognitive functioning that may have not been included in our study.

Monitoring of continuity and transfer of attention with the use of the points matching test did not allow to observe essential effects in analyzed group of patients. Previous article [43] included possible limits, tools, and characteristic features of research group of patients, which could contribute to such a result to a great extent. Use of alternative diagnostic methods could bring further solutions concerning this matter $[87,88]$.

What should be noticed, however, is that essential differences were found between attentive functioning of patients before treatment and after few weeks of therapy measured with the use of attention and perception test. What is interesting, such a result was observed despite of lack of differences in this field of cognitive functioning, which would be observed as a comparison of patients experiencing pain due to chewing organ disorder as well as those who in the course of this illness did not experience pain [44]. The difference observed was expressed in the increase in number of correct answers resulting from a few weeks of therapeutic process; it indicated that lack of pain experienced enhances improvement of attention selectiveness that is ability to choose proper stimulus from general stimuli having an impact on a human being at a given moment. This is the effect that seems to be vital in the context of the whole therapeutic process; it can be expected that together with progress of prosthetic treatment, the patient will present greater ability to process information concerning own illness and treatment, to ignore the thoughts, which are unfavorable for patient's mood as well as pain having every day impact and more effective maintenance of health-promoting actions. Therefore, it seems that this is a good moment to implement education and psycho-education of patients. It is worth noticing that comparison of patients' results in therapeutic process, whose reduction of pain perceived was achieved, managed to get slight better results on average $(\mathrm{M}=11.43$; $\mathrm{SD}=3.68)$ than patients without pain $(\mathrm{M}=9.91, \mathrm{SD}=2.65)$ [44]. It is possible that constant difficulties associated with processing as compared to context of constant impact of pain stimulus on a longer basis, enhances the increase in processing efficiency in case when pain stimulus has been eliminated [89]. Eventually, it must be noted that this effect did not have a reverse influence on improvement of the speed of information processing but only on its accuracy. Meanwhile, what is interesting, it is the first parameter described that is usually substantially lowered in case of chronic pain $[90,91]$. It can be assumed that time perspective without pain could turn out to be too short to observe changes in this scope.

Functioning of patients in the digit span test focusing on description of short-term memory as well as auditory and verbal operative memory improved as compared to starting of treatment [44]. This result suggests that reduction of pain enables fast mental processing of material used for more effective storing of small portions of information in memory and its current processing. Clear improvement of cognitive functioning in these cognitive fields as well as relatively good volume of short-term attention of patients before starting of treatment suggest rather attentive and executive basis of difficulties observed. This effect should be noticed in patients' ability to remember, react to information received during conversation, matching new information with the one already possessed, and maintaining information, also in case when it attracts attention to something else. As memory functions are engaged in a number of everyday tasks (mental counting, speaking, remembering phone number, etc.), an improvement in this field is relatively fast perceived by patient and his/her company.

Process of learning of new material became more efficient. Comparison of performance in auditory and verbal test before and after prosthetic treatment has been implemented with the use of occlusive guards [45], allowed to observe substantial improvement in the number of words recollected by patients on first and fourth revision of acquired information. Therefore, it must be accepted that elimination of pain was connected with essential improvement of quality in gaining information on further stages in the process of learning. This remains coherent with test results by Sanchez [89], where low level of pain, not influencing current processing of information, had an impact on ability to reproduce the information. It must be underlined that in case of changes concerning learning processes being the effect of pain reduction, we assume certain clear, although statistically irrelevant tendency, which became visible during the fifth stage of material revision. Results achieved deliver further arguments in favor of attention or relatively executive basis for the observed difficulties among patients in this group.

Clear decrease in the number of mistakes made 
during go/no-go trials indicate that the ability to inhibit the reaction as a proof for greater control over own behavior has improved together with a decrease in pain intensity. Simultaneously it may be concluded that under the influence of myofascial pain, patients are susceptible to make impulsive mistakes and perform aimless reactions. It means that together with the progress of treatment, patients gained greater self-control that allowed for more organized and unrestricted character of their actions on various levels of their psychological organization, starting from visual and perception phenomena, through notion-cognitive processes and emotional reactions, with motor actions to finish [92]. It is worth underlining that before starting the treatment, the ability to inhibit reaction was comparable in the group of patients with chewing organs disorders who experienced pain, with those who did not have this kind of experience [44], what suggest that the effect observed cannot be explained only by pain reduction. It is a result of other complex therapeutic interventions.

Further changes in the scope of executive functions, so called "supervisory", controlling and managing cognitive activity of a human, were proved by results achieved with the use of Wisconsin cards sorting test. Under the influence of learning process, distinct improvement in the scope of number and correctness of problem tasks solving was observed as well as a decrease in the number of trials carried out necessary to solve problem task. Certainly, the influence of improvement in other fields of cognitive functioning described above on the quality of tasks performed cannot be omitted, including ability to store the purpose of the task in memory, maintain attention that enables following the task and seeing the difference in cards, or improvement in possibility to learn. Nevertheless, the results achieved confirm sensitivity of executive functioning to changes in chronic experiencing of pain.

\section{CONCLUSIONS}

Summing up all the results discussed above, the attention must be paid to the fact that even few weeks of complex pain therapy in temporomandibular disorders, resulting in a reduction of pain intensity, enabled to observe systematic differences in cognitive functioning in the group of patients as compared with the patients' status at the beginning of therapy.

Improvement in cognitive functioning observed comprised memory-related processes, including the scope of auditory and verbal learning of new information, direct auditory memory, auditory and verbal operative memory, perception and attention processes (accuracy) as well as executive processes in the form of ability to inhibit unwanted reactions and ability to solve problem tasks. Analysis of results achieved, pursuant to initial cognitive functioning of this group of patients, allows to draw a conclusion concerning key meaning of neurophysiological changes in frontal fields of brain for the observed changes in cognitive and behavioral functioning in the group observed. These results are coherent with earlier empirical reports indicating changes in activity within dorsolateral prefrontal cortex (DLPFC) and prefrontal cortex (FPC) [92]. Results observed are coherent with research carried out on pain groups stated within other systems, suggesting at least partial reversibility of processes observed, that is the effect of neuroplasticity of brain structures. It seems that the structures mentioned above can initiate reconstruction processes in this scope.

Awareness of changes progressing in cognitive functioning of patients with painful form of chewing organ disorder seems important not only in the context of general well-being of patient, but also essential in the course of further stages of learning process. Control over basic aspects of cognitive functioning of patients may influence strengthening of positive attitude towards learning process and as a result, further stages of learning. Results attract attention to the fact that monitoring of psychological functioning of patients with chewing organ disorders may not be exclusively limited to emotional aspects.

Relatively small group of subjects and rather short time of observation of patients enhance some caution while generalizing the results. Further research should aim at replication of results on a greater group of patients, taking into consideration the dynamics of phenomena observed in a longer time as well as the attempt to estimate the value of different aspects of psychological functioning of patients and various therapeutic impacts in the context of observable somatic changes.

\section{ACKNOWLEDGEMENTS}

We would like to thank Ms. Ewa Jańczak-Biegańska, a dentist, for practical remarks implemented to the shape and course of research project as well as Anna Starowicz-Filip, MA, for consultations on the results achieved.

\section{CONFLICT OF INTEREST}

The authors declare no potential conflicts of interest with respect to the research, authorship, and/or publication of this article.

\section{References}

1. Onozuka M, Fujita M, Watanabe K, et al. Mapping brain region activity during chewing: a functional magnetic resonance imaging study. J Dent Res 2002; 81: 743-746.

2. Bellebaum C, Daum I. Cerebellar involvement in executive control. Cerebellum 2007; 6: 184-192.

3. Cooper FE, Grube M, Elsegood KJ, et al. The contribution of the cerebellum to cognition in spinocerebellar ataxia type 6 . Behav Neurol 2010; 23: 3-15.

4. Ravizza SM, Ivry RB. Comparison of the basal ganglia and cere- 
bellum in shifting attention. J Cogn Neurosci 2001; 13: 285-297.

5. Highnam CL, Bleile KM. Language in the cerebellum. Am J Speech Lang Pathol 2011; 20: 337-347.

6. Molinari M, Leggio MG. Cerebellar information processing and visuospatial functions. Cerebellum 2007; 6: 214-220.

7. Mochizuki-Kawai H. Neural basis of procedural memory. Brain Nerve 2008; 60: 825-832.

8. Marvel CL, Faulkner ML, Strain EC, et al. An fMRI investigation of cerebellar function during verbal working memory in methadone maintenance patients. Cerebellum 2012; 11: 300-310.

9. Misciagna S, Juvone L, Silveri MC. Verbal short-term memory and the cerebellum; evidence from a patient with congenital cerebellar vermis hypoplasia. Neurocase 2010; 16: 119-124.

10. Exner C, Weniger G, Irle E. Cerebellar lesions in the PICA but not SCA territory impair cognition. Neurology 2004; 63: 2132-2135.

11. Levinsohn L, Cronin-Golomb A, Schmahmann JD. Neuropsychological consequences of cerebellar tumor resection in children. Brain 2000; 123: 1041-1050.

12. Maryniak A, Roszkowski M. Zespół poznawczo-emocjonalny u dzieci po resekcji łagodnych guzów móżdżku. Neurol Neurochir Pol 2005; 39: 202-206.

13. Schutter DJ, van Honk J. The cerebellum in emotion reguation: a repetitive transcranial magnetic stimulation study. Cerebellum 2009; 8: 28-34.

14. Schmahmann, JD, Weilburg, JB, Sherman JC. The neuropsychiatry of the cerebellum - insights from the clinic. Cerebellum 2007; 6: 254-267.

15. Hernáez-Goñi P, Tirapu-Ustárroz J, Iglesias-Fernández L, LunaLario P. The role of the cerebellum in the regulation of affection, emotion and behavior. Rev Neurol 2010; 51: 597-609.

16. Fukushima-Nakayama Y, Ono T, Hayashi M, et al. Reduced mastication impairs memory function. J Dent Res 2017; 96: 1058-1066.

17. Kubo KY, Chen H, Onozuka M. The relationship between mastication and cognition. In: Wang Z, Inuzuka H (eds.). Senescence and senescence-related disorders. InTech, Rijeka 2013 pp. 115-132.

18. Chen H, Linuma M, Onozuka M, Kubo KY. Chewing maintains hippocampus-dependent cognitive function. Int J Med Sci 2015; 12: 502-509.

19. Ono T, Yamashita D, Hirano T. Codensin II initiates sister chromatid resolution during S phase. J Cell Biol 2013; 200: 429-441.

20. Whitlock JR, Heynen AJ, Shuler MG, Bear MF. Learning induces long-term potentiation in the hippocampus. Science 2006; 313 1093-1097.

21. Hirano Y, Obata T, Kashikura K, et al. Effects of chewing in working memory processing. Neurosci Lett 2008; 436: 189-192.

22. Hirano Y, Obata T, Takahashi $\mathrm{H}$, et al. Effects of chewing on cognitive processing speed. Brain Cogn 2013; 8: 376-381.

23. Takada T, Miyamoto T. A fronto-parietal network for chewing of gum: a study on human subjects with functional magnetic resonance imaging. Neurosci Lett 2004; 360: 137-140.

24. World Health Organization, WHO 1964.

25. Fillingim RB, Ohrbach R, Greenspan JD, et al. Psychological factors associated with development of TMD: The OPERA perspective cohort study. J Pain 2013; 14: T75-T90.

26. Martins RJ, Garbin CAS, Garcia AR, et al. Stress levels and quality of sleep in subjects with temporomandibular joint dysfunction. Rev Odonto Ciênc 2010; 25: 32-36.

27. Bertolli E, de Leeuw R, Schmidt JE, et al. Prevalance and impact of post-traumatic stress disorder symptoms in patients with masticatory muscle or temporomandibular joint pain: differences and similarities. J Orofac Pain 2007; 21: 107-119.

28. Glaros AG, Williams K, Lauste L. The role of parafunctions, emotions and stress in predicting facial pain. J Am Dent Assoc 2005; 136: 451-458

29. Callahan CD. Stress, coping and personality hardiness in patients with temporomandibular disorders. Rehabilitation Psychology 2000; 45: 38-48.

30. Jones DA, Rollman GB, Brooke RI. The cortisol response to psy- chological stress in temporomandibular disrodes. Pain 1997; 72: 171-182.

31. Rugh JD, Woods BJ, Dahlstrom L. Temporomanidubular disorders: assessment of psychological factors. Adv Dent Res 1993; 7: 127-136.

32. Speculand B, Huhes AO, Goss AN. Role of recent stressful life events experience in the onset of TMS dysfunctional pain. Community Dent Oral Epidemiol 1984; 12: 197-202.

33. Fearon CG, Serwatka WJ. Stress: a common denominator for nonorganic TMJ pain-dysfunction. Journal Prosthet Dent 1983; 49: 805-812.

34. Stein S, Hart DL, Loft G, Davis H. Symptoms of TMJ dysfunction as related to stress measured by the social readjustment rating scale. J Prosthet Dent 1982; 47: 545-548.

35. Pihut M, Gierowski K, Ceranowicz P. Psychoemocjonalne podłoże zespołu zaburzeń czynnościowych narządu żucia. Lett Drug Des Discov 2015; 12: 766-770.

36. Lavigne GJ, Kato T, Kolta A, Sessl BJ. Neurobiological mechanisms involed in sleep bruxism. Crit Rev Oral Biol Med 2003; 14: 30-46.

37. Chen D, Ji X, Harris MA, et al. Differential roles for bone morphogenetic protein (BMP) receptor type IB and IA in differentiation and specification of mesenchymal precursor cells to osteoblast and adipocyte lineages. J Cell Biol 1998; 142: 295-305.

38. Cohen MJ, Song ZK, Schandler SL, et al. Sensory detection and pain thresholds in spinal cord injury patients with and without dysesthetic pain, and in chronic low back pain patients. Somatosens Mot Res 1996; 13: 29-37.

39. Laskin DM. Etiology and the pain-dysfunction syndrome. J Am Dent Assoc 1969; 79: 147-153.

40. Okeson JP. Bell's Oral and Facial Pain. $7^{\text {th }}$ ed. Quintessence Publishing Co, Inc., Chicago 2014.

41. Teixeira FB, Fernandes LM, Noronha PA, et al. Masticatory deficiency as a risk factor for cognitive dysfunction. Int J Med Sci 2014; 11: 209-214.

42. Smith N, Miquel-Kergoat S, Thuret S. The impact of mastication on cognition: evidence for intervention and the role of adult hippocampal neuro genesis. Nutrition Aging 2016; 3: 115-123.

43. Biegańska-Banaś J, Gierowski J, Ferendiuk E, et al. In quest of the longest and most annoying pain for patients and for dentists. Quantitative and qualitative characteristics of temporomandibular myofascial pain dysfunction syndrome - questionnaire study. Health Psychol Rep 2018; 6: 222-242.

44. Biegańska-Banaś J, Ferendiuk E, Gierowski J, Pihut M. Cognitive functioning and myofascial pain in temporomandibular disorders. J Stoma 2018; 71: 277-287.

45. Miller LR, Cano A. Comorbid chronic pain and depression: who is at risk? J Pain 2009; 10: 619-627.

46. Munoz M, Esteve R. Reports of memory functioning by patients with chronic pain. Clin J Pain 2005; 21: 287-291.

47. Apkarian AV, Shi T. Thalamocortical connection of the cingulate and insula in relation to nociceptive inputs to the cortex. In: Pain Mechanisms and Management. Ayrapetyan SN, Apkarian AV (eds.). IOS Press, Amsterdam 1998, p. 212-220.

48. Bushnell MC, Duncan GH, Hofbauer RK, et al. Pain perception: is there a role for primary somatosensory cortex? Proc Natl Acad Sci USA 1999; 96: 7705-7709.

49. Geha PY, Baliki MN, Harden RN, et al. The brain in chronic CRPS pain: abnormal gray-white matter interactions in emotional and autonomic regions. Neuron 2008; 60: 570-581.

50. Lutz J, Jäger L, de Quervain D, et al. White and gray matter abnormalities in the brain of patients with fibromyalgia: a diffusion-tensor and volumetric imaging study. Arthritis Rheum 2008; 58: 3960-3969.

51. Gerstner G, Ichesco E, Quintero A, Schmidt-Wilcke T. Changes in regional gray and white matter volume in patients with myofascial-type temporomandibular disorders: a voxel-based morphometry study. J Orofac Pain 2011; 25: 99-106.

52. Moayedi M, Weissman-Fogel I, Salomons TV, et al. White matter brain and trigeminal nerve abnormalities in temporomandibular disorder. Pain 2012; 153: 1467-1477. 
53. Draganski B, Moser T, Lummel N, et al. Decrease of thalamic gray matter following limb amputation. Neuroimage 2006; 31: 951-957.

54. Wrigley PJ, Gustin SM, Macey PM, et al. Anatomical changes in human motor cortex and motor pathways following complete thoracic spinal cord injury. Cereb Cortex 2009; 19: 224-232.

55. Yu HJ, Christodoulou C, Bhise V, et al. Multiple white matter tract abnormalities underlie cognitive impairment in RRMS. Neuroimage 2012; 59: 3713-3722.

56. van Noordt S, Good D. Mild head injury and sympathetic arousal: investigating relationships with decision-making and neuropsychological performance in university students. Brain Inj 2011;25 707-716.

57. Sigurdardottir S, Jerstad T, Andelic N, et al. Olfactory dysfunction, gambling task performance and intracranial lesions after traumatic brain injury. Neuropsychology 2010; 24: 504-513.

58. Bechara A, Damasio H, Damasio AR. Emotion, decision making and the orbitofrontal cortex. Cereb Cortex 2000; 10: 295-307.

59. Seminowicz DA, Wideman TH, Naso L, et al. Effective treatment of chronic low back pain in humans reverses abnormal brain anatomy and function. J Neurosci 2011; 31: 7540-7550.

60. Rodriguez-Raecke R, Niemeier A, Ihle K, et al. Brain gray matter decrease in chronic pain is the consequence and not the cause of pain. J Neurosci 2009; 29: 13746-13750.

61. Boyke J, Driemeyer J, Gaser C, et al. Training-induced brain structure changes in the elderly. J Neurosci 2008; 28: 7031-7035.

62. May A. Chronic pain may change the structure of the brain. Pain 2008; 137: 7-15.

63. Teutsch S, Herken W, Bingel U, et al. Changes in brain gray matter due to repetitive painful stimulation. Neuroimage 2008; 42: 845-849.

64. Draganski B, Gaser C, Busch V, et al. Neuroplasticity: changes in grey matter induced by training. Nature 2004; 427: 311-312.

65. Rodriguez-Raecke R, Niemeier A, Ihle K, et al. Structural brain changes in chronic pain reflect probably neither damage nor atrophy. PLoS One 2013; 8: e54475.

66. Stós B, Pihut M, Gala A. Szyny okluzyjne stosowane powszechnie w protetycznej rehabilitacji zaburzeń czynnościowych narządu żucia. Poradnik Stomatologiczny 2004; 3: 5-10.

67. Pihut M, Wisniewska G, Majewski S. Ocena skuteczności relaksacji wybranych mięśni żucia pod wpływem stosowania szyn okluzyjnych za pomocą badań elektromiograficznych. Czas Stomatol 2007; 60: 473-482.

68. Chruściel-Nogalska M, Polak-Majcher D, Dalewski B, Frączak B. Przegląd stosowanych szyn zgryzowych w leczeniu zaburzeń czynnościowych układu stomatognatycznego - na podstawie piśmiennictwa. Dental Forum 2013; 2: 63-66.

69. Kazana P, Pihut M, Kazana M. Analiza współpracy stomatologów i fizjoterapeutycznych w leczeniu zaburzeń czynnościowych układu stomatognatycznego na podstawie badań ankietowych. Implantoprotetyka 2011; 12: 44-45.

70. Biegańska-Banaś I, Pihut M. Psychoedukacja w zakresie radzenia sobie ze stresem - możliwości zastosowania jako metody wspomagającej terapię zaburzeń czynnościowych narządu żucla. E-Dentico 2016; 59: 126-131.

71. Pihut M, Biegańska-Banaś J, Urbański P. Psychoeducation training in stress management strategies as adjunct therapy in temporomandibular joint dysfunction - preliminary study. Arch PP 2016; 1: $43-47$.

72. Bieganska J, Pihut M. Psychoeducation program on strategies for coping with stress in patients with temporomandibular joint dysfunction. Biomed Res Int 2014; 2014: 678169.

73. dos Santos Calderon P, de Lourdes Merighi Tabaguim M, de Oliveira LC, et al. Effectiveness of cognitive-behavioral therapy and amitriptyline in patients with chronic temporomandibular disorders: a pilot study. Braz Dent J 2011; 22: 415-421.

74. Litt MD, Shafer DM, Kreutzer DL. Brief Cognitive-Behavioral Treatment for TMD Pain: Long-Term Outcomes and Moderators of Treatment. Pain 2010; 151: 110-116

75. Berlucchi G, Buchtel HA. Neuronal plasticity: historical roots and evolution of meaning. Exp Brain Res 2009; 192: 307-319.
76. Gustin SM, Wrigley PJ, Siddall PJ, Henderson LA. Brain anatomy changes associated with persistent neuropathic pain following spinal cord injury. Cereb Cortex 2010; 20: 1409-1419.

77. Wiech K, Ploner M, Tracey I. Neurocognitive aspects of pain perception. Trends Cogn Sci 2008; 12: 306-313.

78. Strauss E, Sherman E, Spreen O. A Compendium of neuropsychological tests: Administration, norms, and commentary. $3^{\text {rd }}$ ed. Oxford University Press, New York 2006.

79. Levine B, Turner GR, Tisserand D, et al. The functional neuroanatomy of episodic and semantic autobiographical remembering: a prospective functional MRI study. J Cogn Neurosci 2004, 16: $1633-1646$.

80. Basso MR, Bornstein RA, Lang JM. Practice effects on commonly used measures of executive function across twelve months. Clin Neuropsychol 1999; 13: 283-292.

81. Lezak MD, Howieson DB, Bigler ED, Tranel D. Neuropsychological assessment. $5^{\text {th }}$ ed. Oxford University Press, New York 2012.

82. Szepietowska EM, Gawda B. Ścieżkami fluencji werbalnej. Wyd. UMCS, Lublin 2011.

83. Baldo JV, Schwartz S, Wilkins D, Dronkers NF. Role of frontal versus temporal cortex in verbal fluency as revealed by voxel-based lesion symptom mapping. J Int Neuropsychol Soc 2006; 12: 896900 .

84. Henry JD, Crawford JR. A meta-analytic review of verbal fluency performance following focal cortical lesions. Neuropsychology 2004; 18: 284-295.

85. Rusu AC, Pincus T. Chronic pain patients' perceptions of their future: a verbal fluency task. Pain 2017; 158: 171-178.

86. Weissman-Fogel I, Moayedi M, Tenenbaum HC, et al. Abnormal cortical activity in patients with temporomandibular disorder evoked by cognitive and emotional tasks. Pain 2011; 152: 384-396.

87. Dick B, Eccleston C, Crombez G. Attentional functioning in fibromyalgia, rheumatoid arthritis, and musculoskeletal pain patients. Arthritis Rheum 2002; 47: 639-644.

88. Sanchez CA. Working through the pain: working memory capacity and differences in processing and storage under pain. Memory 2011; 19: 226-232.

89. Grigsby J, Rosenberg NL, Busenbark D. Chronic pain is associated with deficits in information processing. Perceptual Motor Skills 1995; 81: 403-410.

90. Lee DM, Pendleton N, Tajar A, et al. Chronic widespread pain is associated with slower cognitive processing speed in middle-aged and older European men. Pain 2010; 151: 30-36.

91. Jodzio K. Diagnostyka neuropsychologiczna w praktyce klinicznej. Difin, Warszawa 2011.

92. Moayedi M, Weissman-Fogel I, Crawley AP, et al. Contribution of chronic pain and neuroticism to abnormal forebrain gray matter in patients with temporomandibular disorder. Neuroimage 2011; 55: 277-286. 